\title{
Public Funding and Enrollment in Formal Child Care in the 1990s
}

\author{
Katherine A. Magnuson \\ University of Wisconsin-Madison
}

Marcia K. Meyers

University of Washington

Jane Waldfogel

Columbia University

\begin{abstract}
Although the share of all 3- and 4-year-old children enrolled in center-based care and early education has grown steadily in recent decades, rates of enrollment for children from low-income families still lag behind those for children from families with high incomes. During the 1990s, growing public funding for compensatory preschool education and means-tested child-care assistance had the potential to increase the availability of free or low-cost formal child-care arrangements and thus the attendance of low-income children. This article analyzes repeated cross-sectional data on formal child-care attendance from the October Current Population Survey as well as data on state-level funding. The results indicate that increases in public funding are positively associated with the probability that low-income young children attended formal care. These results also suggest that gaps in formal care between low- and high-income families would have widened in the absence of public investments.
\end{abstract}

The share of all U.S. preschool-age children participating in centerbased child care and early education has grown substantially in recent years. Indeed, the majority of young children now experience formal child care before they enter elementary school. Using data from the U.S. Census Bureau's Current Population Survey (CPS), Jay Bainbridge and colleagues (2005) find that, between 1968 and 2000, the enrollment rate of 3-year-olds rose from 8 to 39 percent, while the enrollment rate of 4-year-olds rose from 23 to 65 percent. However, young children in low-income families are less likely than their higher-income counterparts

Social Service Review (March 2007).

(C) 2007 by The University of Chicago. All rights reserved.

0037-7961/2007/8101-0004\$10.00 
to be in center-based care arrangements (Federal Interagency Forum on Child and Family Statistics 2003; Meyers et al. 2004).

Children's cognitive abilities are also very unequal by the time they start school. For example, data from the Early Childhood Longitudinal Survey, Kindergarten Class of 1998-99, indicate that low-income children score lower than more affluent children on four dimensions of school readiness: cognitive skills and knowledge, social skills, physical health and well-being, and approaches to learning (West, Denton, and Germino-Hausken 2000; Lee and Burkam 2002). Moreover, early disparities in academic outcomes are likely to persist into later childhood and adolescence (Caneiro and Heckman 2003).

Sorting out the causes of educational disparities is a complex task. Nevertheless, research suggests that differential exposure to high-quality center-based care and early education may be one contributing factor. A large body of evidence demonstrates that children who attend these programs enter school with better academic skills than children who have not attended such programs (Shonkoff and Phillips 2000; Smolensky and Gootman 2003). Moreover, low-income children and children whose parents have low levels of education experience the largest and most lasting benefits from attending center-based care and early education programs (Karoly et al. 1998; Currie 2001; Magnuson et al. 2004). Disparities in children's exposure to educationally enriching early care are particularly worrisome, given this evidence. Compared to children in higher-income, and better-educated families, children in lower-income and less well-educated families may be doubly disadvantaged by living in less educationally stimulating homes and having less access to educationally enhancing early child care. This compounded disadvantage in early childhood may have lasting effects on social and economic opportunities later in life (Caneiro and Heckman 2003).

In response to increased demand among working mothers for highquality child care and as a result of a growing recognition that centerbased care and early education programs prepare children for formal schooling, federal and state governments have expanded funding for compensatory early education programs and for means-tested child-care subsidies. It is not known whether or to what extent this expansion has increased the enrollment of low-income children in educationally enriching programs. Whereas Head Start monies can only be used to provide early education for low-income children, means-tested childcare subsidies may be used for many types of child care, and some features of subsidy programs (e.g., high copayments) may discourage parents from using formal care arrangements (Meyers et al. 2004).

This article explores the effects of public funding on formal childcare enrollment. The analyses use repeated cross-sectional measures from 1992 to 2000 of enrollment in center-based child care and early education. Throughout the article, both of these will be referred to as 
formal child care. ${ }^{1}$ Results suggest that expansions in public funding increased the likelihood that low-income children were enrolled in some type of formal care. The magnitude of the association suggests that nearly half of the increase in enrollment in formal child care among low-income children during this time may be attributed to the expansions in public funding. Although income-related enrollment disparities persist, the findings suggest that income-related gaps in early education would probably have been larger in the absence of the funding increases.

\section{Background}

The proportion of young children experiencing center-based child care and early education has risen dramatically in the recent past (Bainbridge et al. 2005). This rise in formal care was driven both by an increase in maternal employment, particularly among mothers with young children, and by an increased emphasis on the importance of early learning.

Parents with young children choose nonparental care arrangements from an array of informal and formal care programs. Informal care is often provided by nannies, neighbors, and relatives. Formal care may be provided by schools, as well as by for-profit and nonprofit providers of early education and child care. Although early education programs presumably differ from center-based child care in the extent to which early learning is emphasized by program staff and perhaps in the hours of operation, the distinction between these types of programs is increasingly blurred. Many programs of both types now address the dual goals of supporting working families and providing enriching learning environments. Early education programs often offer extended hours to provide wrap-around child care (i.e., care offered before or after preschool sessions), and child-care centers use early learning curricula (Adams and Rohacek 2002).

Parents face a complex array of child-care and early education choices as they try to balance competing concerns. Thus, it is not surprising that their decisions are influenced by several factors, including personal preferences, family structure, employment, and the local availability of formal and informal care providers (Singer et al. 1998; Pungello and Kurtz-Costes 1999; Huston, Chang, and Gennetian 2002; Meyers and Jordan 2006). The cost of formal care and families' economic resources are particularly important influences on families' care choices. With the cost of full-time private preschool or center-based care during the 1990s averaging $\$ 4,000-\$ 6,000$ per year, center-based child-care and early education arrangements were prohibitively expensive for many low-income families, as such costs would often consume as much as one-quarter of their income (Blank, Schulman, and Ewen 1999; Rosenbaum and Ruhm 2005). The high price of formal child care depresses both maternal employment and the use of this type of care, particularly among low- 
income, low-skilled, and single mothers (Hofferth and Wissoker 1992; Anderson and Levine 2000; Blau 2001). The costs of private early education programs are equally high, and the availability of publicly funded early education programs is limited. Many low-income parents may thus be priced out of such programs (Smolensky and Gootman 2003).

\section{Child-Care Policies}

The United States addresses income-related disparities in early education and in child-care enrollment through two parallel policies: compensatory early education programs and means-tested child-care-assistance programs. ${ }^{2}$ Federal and state investments in both areas grew substantially in recent years, although such programs continue to serve only a portion of low-income children (Smolensky and Gootman 2003).

Compensatory early education programs are most explicitly targeted at reducing inequality in early education. These programs aim to increase school readiness and decrease human capital deficits by providing early education services to 3- and 4-year-old children from low-income families. Head Start remains the single largest compensatory early education effort. Federal appropriations for Head Start increased 250 percent between 1990 and 2000, totaling nearly $\$ 5.3$ billion in 2000 (USDHHS [U.S. Department of Health and Human Services], Administration for Children and Families 2001). Head Start funding is disbursed directly to about 1,500 private and public nonprofit organizations, which served 857,644 low-income or disabled children in 2000 (USDHHS, Administration for Children and Families 2001; Butler and Gish 2003).

Some states and local school districts now fund early education programs, which are often called prekindergarten programs. State funding for prekindergarten increased during the 1990 s to reach about $\$ 1.9$ billion in 2000, and recent estimates suggest that 17 percent of 4-year-olds are enrolled in prekindergarten programs (Barnett et al. 2005). These programs vary in the amount and types of early education they provide. Most states provide part-day services to children who, based on their family or community characteristics, are deemed in need of early education. Some states subcontract with existing early education providers; others deliver services within public school settings. State prekindergarten initiatives are not intended to supplant Head Start services, and during the 1990s, the bulk of state investments in prekindergarten was concentrated in just a few states (Blank et al. 1999).

The second track in U.S. policy, means-tested child-care assistance, reduces the cost of nonparental care for low-income families by subsidizing private, market-based child care. Subsidies are provided for all types of care, including center-based care, early education programs, 
and informal care by family child-care providers, friends, relatives, and babysitters. The federal government currently funds means-tested childcare assistance through three block grants to the states. These funds are used to assist families by directly paying private providers or (more commonly) through vouchers issued to reimburse private providers or parents (Smolensky and Gootman 2003). States contribute their own funding through maintenance of effort (MOE) expenditures (i.e., expenditures that states are required to make in order to continue to receive federal funding at the same level as they have in previous years), and some states choose to further supplement federal monies.

Federal and state funding for means-tested child-care assistance has grown sharply in recent years as a result of welfare reform. The single largest federal block grant is the Child Care and Development Fund (CCDF), which was established in 1996 to replace and consolidate several prior child-care funding programs (Meyers et al. 2004). Currently, states can use CCDF funds to serve families with incomes up to 85 percent of the state median income (although many states set a lower threshold). Parents must be working or in school to qualify for assistance. States must offer parents a choice of care types and providers but are free to set parental copayment and provider reimbursement rates as well as procedures for establishing and recertifying eligibility.

The second major current funding stream for means-tested child-care assistance is the Temporary Assistance for Needy Families (TANF) block grant, which replaced the Aid to Families with Dependent Children (AFDC) program in 1996. States may transfer up to 30 percent of their TANF funds to CCDF; about half the states currently commit some TANF funds to CCDF (Gish 2002). States can also use TANF funds to subsidize child care directly (largely through vouchers). These funds typically assist welfare-reliant families in which the parent is working, in education, or in training, as well as former welfare recipients who are now employed. ${ }^{3}$ The Social Services Block Grant (SSBG) is the third and smallest source of federal child-care assistance for poor families. In 1999, approximately 13 percent of SSBG funds were used for child-care services or vouchers (Gish 2002).

State and federal funding for child-care subsidies increased dramatically during the 1990s, from a combined total of $\$ 1.7$ billion in 1992 to $\$ 9.5$ billion in 2000 (Gish 2002). Federal investments eclipse state funding. Combined spending for the three block grants (CCDF, TANF, and SSBG) approached $\$ 7$ billion in 2000, constituting 42 percent of all federal investment in early childhood care and education (Gish 2002).

Although federal and state funding is provided through distinct funding streams, these funds may be pooled in several ways. Some states combine all of their funding for means-tested child-care subsidies into a single delivery system. Local program providers may use multiple fund- 
ing streams in order to offer full-day services, including early education, child care, and wrap-around care (Witte and Trowbridge 2004). Parents may rely on multiple forms of assistance to offset the costs of their care arrangements (Meyers et al. 2004).

\section{Child-Care Policy and Enrollment in Formal Care}

If high prices discourage low-income families from accessing formal care, the expansion of means-tested assistance during the 1990s should have enabled more low-income parents to enroll their young children in formal care. Because low-income parents are often priced out of formal care, it is not surprising that the use of formal care increases when policies lower the costs of child care (Blau and Hagy 1998; Blau 2001; Michalopoulos and Robins 2002; Powell 2002). However, the specific associations between the availability of public child-care assistance and the care arrangements of low-income children are not well understood.

Estimating the effects of subsidy receipt is complicated because it may be endogenous to both employment decisions and child-care arrangements. As a result, in a small number of cross-sectional studies, researchers model child-care arrangements and maternal employment as jointly determined decisions, examining the extent to which access to subsidies promotes maternal employment in combination with particular types of care (Blau and Hagy 1998; Michalopoulos and Robins 2000; Powell 2002; Tekin 2004). In addition, these studies typically rely on some form of exogenous variation in access to subsidies, often state or local policies, to proxy for subsidy use. For example, Erdal Tekin (2004) predicts subsidy receipt with state-level data on the number of children who receive child-care subsidies and CCDF funding. He finds that receiving subsidies predicts the use of formal child care among low-income single mothers with young children. Subsidy receipt increases the probability of combining maternal employment with center-based care by 33 percent but has less effect on the likelihood of combining employment with informal sources of care.

Another set of studies relies on experimental welfare-to-work programs, some of which offered enhanced child-care assistance, as a source of exogenous variation in access to child-care support (Crosby, Gennetian, and Huston 2005; see also Fuller et al. 2002). In a review of several experimental studies, Danielle Crosby and colleagues (2005) find that a 7 percentage point increase in the use of formal child care among 3-5-year-olds can be attributed to enhanced child-care assistance policies. Enhanced assistance, however, is broadly defined in these studies to include not only more generous subsidies but also resource and referral services as well as direct payments to providers. Thus, the increased use of center care among welfare populations cannot simply be attributed to increased funding for child-care subsidies. 
Prior research suggests that the expansion of means-tested compensatory education and child-care subsidies during the 1990s should increase the probability that low-income children experienced formal care, but research provides little guidance as to the relative magnitude of the associations. The expansion of compensatory education programs, such as Head Start, is likely to have the largest direct effect on formal care enrollment by expanding the supply of low-cost or free preschool slots for low-income children. The expansion of CCDF, TANF, and SSBG funding for child-care assistance is also expected to increase the participation of low-income children in formal care, as it reduces the cost of such care for parents. The potential positive effects of expanded public funding, however, may be tempered by several complicating factors.

First, a portion of the expanded funding may have been spent to increase the quality of programs and the hours that children are served rather than to enroll additional children in formal care. These considerations may be particularly relevant for Head Start. Since 1992, 25 percent of the increases in Head Start funding was earmarked for quality improvement; funds may also be used to provide extended hours of care or full-day programs rather than to enroll additional children (Butler and Gish 2003; Besharov and Higney 2006).

Second, expanded funding for unconstrained child-care subsidies (i.e., those subsidies that permit parents to use any type of care) may increase the overall use of nonparental care but have limited effects on the use of formal care because parents may use the subsidies to pay for informal care by family, friends, and family child-care providers, as well as for center-based care and early education programs. The effects of child-care-assistance expenditures on formal care enrollment may also be influenced by state child-care policies and administrative processes that govern eligibility, application procedures, family copayment rates, and provider reimbursement (Adams, Snyder, and Sandfort 2002; Fuller et al. 2002; Meyers, Heintze, and Wolf 2002; Gennetian et al. 2004). For example, low provider-reimbursement rates may depress parents' use of formal care by limiting the supply of center-based child-care and early education programs willing to accept subsidies. High copayments may divert parents away from expensive modes of care, such as preschools. Local agency intake, application, and referral procedures may also affect parents' knowledge and choice of care arrangements; if state officials and agency staff seek to stretch available dollars to cover as many recipients as possible, they may encourage families to use types of care that are less expensive than formal child-care programs.

Third, the extent to which additional public funding increases the percentage of children who experience formal child care also depends on the extent to which low- and no-cost alternatives are substituted for already existing formal care arrangements. If low-income parents are 


\section{Social Service Review}

entirely priced out of formal care, the availability of subsidized preschool slots and means-tested vouchers could lead them to substitute formal care for parental care or other informal arrangements. However, in the absence of subsidized care, low-income parents might be able to arrange for some type of formal care by, for example, using public school-based prekindergarten or negotiating the price with the provider. In this situation, the availability of free or low-cost alternatives might shift children between preschool settings, offset the costs of existing arrangements, or increase the amount of time children spend in formal care, but such availability would not increase the proportion of children who experience formal care.

Finally, the extent to which expanded funding for child care promotes children's enrollment in formal child care also depends on the characteristics of the families and children who gain access to child-care assistance and early education programs. Prior research suggests that the employment and child-care decisions of single mothers are more sensitive to child-care prices than are the decisions of their married counterparts. Married mothers tend to have more resources available to pay for care and may also rely on a partner to provide some hours of care (Anderson and Levine 2000). Thus, increased child-care funding might have a greater effect on formal child-care enrollment among single-mother families than it does on such enrollment among marriedcouple families. The effects of funding expansions on enrollment may also vary with child age. Throughout the 1990s, enrollment rates in formal care were markedly higher for 4-year-olds than for 3-year-olds. This difference perhaps reflects the greater availability of low-cost programs, such as prekindergarten, for 4-year-olds (Bainbridge et al. 2005). Consequently, increases in early education and child-care funding during the 1990s may have a larger effect on the probability of formal care enrollment among 3-year-olds than among 4-year-olds.

\section{Research Questions}

Prior research suggests that the large increase in public funding for compensatory education programs and means-tested subsidies in the 1990s may have increased low-income families' use of child care, particularly of formal care in child-care centers or early education programs. To date, the size of this effect has not been empirically estimated, perhaps in part because doing so is difficult. States do not collect comparable data over time on formal care enrollment or program quality. In addition, few studies with large and nationally representative samples track young children's experiences in formal care. Most studies that collected detailed information from parents about early education and child-care arrangements were fielded only at one or two time points during the 1990s. The only study that repeatedly surveyed parents about 
early education and formal center-based care programs is the U.S. Census Bureau's annual October CPS, which includes basic questions about the enrollment of 3- and 4-year-old children in school or school-like arrangements.

The analyses in this article make use of repeated cross-sectional data from the annual October CPS (from 1992 to 2000) to examine whether and to what extent increases in public spending for compensatory education programs and means-tested child-care assistance predict increases in low-income children's participation in formal care. With rates of enrollment in center-based child care and early education increasing among low-income children, to what extent do increases in Head Start and child-care funding explain these increased levels of enrollment? Do effects differ according to children's ages or their mother's marital status?

Data

The annual October CPS collects demographic information from parents and also includes an education module that surveys parents about the school attendance of 3- and 4-year-olds. It has been fielded annually since 1968. For the analyses, these CPS microdata are combined with state-level information on child-care and Head Start expenditures, the two largest sources of public funding for early education and child care, as well as with data on other state demographic, political, and policy factors. Some analyses also make use of estimated state prekindergarten expenditures. The sample is limited to families surveyed in the CPS between 1992 and 2000, because these are the years for which consistent and reliable data about child-care and early education funding are available. The sample is also limited to families from relatively large states, since the data from smaller states may not provide reliable information on trends in preschool enrollment.

\section{Formal Care}

The outcome measure is the enrollment of 3- or 4-year-old children in formal child care. The October CPS tracks school enrollment by asking respondents whether children age 3 and older attend school. A child is coded as being in formal care if the child's parent answered affirmatively to this question. Thus, in this article, the term "formal care" refers to any program that the respondent identifies as a school. ${ }^{4}$

To explore whether the CPS measure of school enrollment results in similar information as measures of formal child care used in other surveys, it is useful to compare the 1999 October CPS data with detailed data from the National Household Education Survey (NHES) for 1999, the Early Childhood Longitudinal Study-Kindergarten Cohort (ECLSK) for 1998, and the National Survey of America's Families (NSAF) for 
1999. These comparisons indicate that the measure of school enrollment in the October CPS is similar to measures in other studies that include center-based care, Head Start, nursery school, and prekindergarten. For example, the NHES estimates of the proportions of 3- and 4-year-olds attending center-based care in 1999 (46 percent for 3-year-olds and 70 percent for 4-year-olds) are quite similar to the October CPS estimates of children's school attendance for that year ( 40 percent and 68 percent, respectively; authors' calculations). The NHES definition of centerbased care includes day-care centers, nursery schools, prekindergartens, preschools, and Head Start programs. An analysis of the ECLS$\mathrm{K}$ data also yields comparable estimates for 4-year-olds' attendance in center-based care and Head Start (69 percent) in 1997 (authors' calculations). With respect to 3-year-olds, findings from the NSAF parallel those from other sources (38 percent attend center-based care), but rates of enrollment for 4-year-olds are slightly lower (61 percent; authors' calculations). The NSAF definition of center-based care includes school, prekindergarten, preschool, day-care centers, and Head Start. The NSAF's lower enrollment rates for 4-year-olds probably reflect a discrepancy in the timing of the assessment. The NSAF was administered throughout the year, and thus some respondents were surveyed during the summer months when educational programs may not have been in session. In sum, the CPS measure used here is likely to capture nearly all forms of center-based care and early education. It also seems likely that parents in the CPS do not identify informal child care and family child care as school, even when such care is licensed. ${ }^{5}$ Thus, although the annual October CPS differs from other studies by asking about school rather than nonparental care arrangements, this measure yields similar information about children's participation in center-based care and early education programs. This article describes both types of programs as formal child care.

It is important to note one question change in the annual October CPS. Prior to 1994, parents were asked, "Does your child attend regular school?" In 1994, the CPS added a prompt to clarify that "regular school includes nursery school, kindergarten, or elementary school and schooling which leads to a high school diploma." The addition of this prompt might influence reported enrollment rates. This is handled in these analyses by including year fixed effects. Trends in enrollment for children from low- and higher-income families in the sample are provided in table 1.

\section{Income}

The October CPS collects categorical income data by asking respondents which income range represents the total combined income of all members of the family residing in the household during the preceding 12 
Table 1

Formal Care Enrollment and Public Funding Per Child, 1992-2000

\begin{tabular}{|c|c|c|c|c|c|c|}
\hline Year & $\begin{array}{c}\text { Low- } \\
\text { Income } \\
\text { Enrollment } \\
(\%)\end{array}$ & $\begin{array}{c}\text { Higher- } \\
\text { Income } \\
\text { Enrollment } \\
(\%)\end{array}$ & $\begin{array}{l}\text { Gap } \\
(\%)\end{array}$ & $\begin{array}{c}\text { Total } \\
\text { Funding } \\
(\$)\end{array}$ & $\begin{array}{c}\text { Child-Care } \\
\text { Subsidies } \\
(\$)\end{array}$ & $\begin{array}{c}\text { Head } \\
\text { Start } \\
(\$)\end{array}$ \\
\hline 1992 & 31.85 & 44.48 & 12.63 & 452 & 238 & 213 \\
\hline 1993 & 35.68 & 43.98 & 8.32 & 499 & 251 & 247 \\
\hline 1994 & 41.86 & 49.87 & 8.01 & 535 & 255 & 280 \\
\hline 1995 & 39.82 & 51.84 & 12.02 & 575 & 293 & 282 \\
\hline 1996 & 38.66 & 54.54 & 15.88 & 567 & 287 & 280 \\
\hline 1997 & 46.60 & 55.20 & 8.60 & 622 & 320 & 302 \\
\hline 1998 & 43.47 & 54.42 & 10.95 & 825 & 491 & 335 \\
\hline 1999 & 44.47 & 55.89 & 11.42 & 1,004 & 641 & 362 \\
\hline 2000 & 48.70 & 52.51 & 3.81 & 1,215 & 827 & 388 \\
\hline $\begin{array}{l}\text { Increase in enrollment, } \\
1992-2000\end{array}$ & 16.85 & 8.03 & NA & NA & NA & NA \\
\hline $\begin{array}{l}\text { Increase in funding, } \\
1992-2000\end{array}$ & NA & NA & NA & 796 & 589 & 175 \\
\hline
\end{tabular}

Note. - NA = not applicable. All amounts (total funding, child-care subsidies, and Head Start) have been adjusted for inflation (using the consumer price index) and divided by the number of poor children under age 13 in a state. Low income refers to families with incomes in the bottom $25 \%$ of the family income distribution in the sample; higher income refers to families with incomes in the top $75 \%$ of the distribution. This table provides information for the sample of children used in this study. Table A3 in the appendix provides these data for the full sample from the U.S. Census Bureau's October Current Population Survey.

months. Because of inflation, income categories are not strictly comparable across years. As a result, in these analyses, children are classified into income quartiles for families in households with young children of ages 3 and 4 . If the rank order from rich to poor is roughly correct in each year, low-income families (the bottom quartile, representing the lowest 25 percent of family incomes) can be reliably distinguished from higher-income families (the top three quartiles, representing the highest 75 percent of family incomes). The analyses also include year dummy variables, which will correct for any changes in the composition of the low-income sample over time.

From 1992 to 1995, families in the lowest quartile reported family household incomes less than $\$ 15,000$; from 1996 to 1998 , these families had incomes of less than $\$ 20,000$; in 1999 and 2000, they had incomes of less than $\$ 25,000$. This categorization of low income roughly captures the proportion of families that may be eligible for child-care assistance by the end of the 1990s. In 2000, the average state income eligibility threshold was 59 percent of a state's median income. This threshold is about $\$ 24,869$ if the national median income is used as the base (U.S. Census Bureau 2003). This categorization also is consistent with the percentage of young children who were living in poverty in the early 
and mid-1990s (approximately 23-24 percent). By the late 1990s, poverty rates among young children declined to under 20 percent (USDHHS, Office of the Assistant Secretary for Planning and Evaluation 2001). Thus, the lowest income category is not as consistent with the share of children in poverty in the later years. For example, in 2000, the poverty threshold was $\$ 13,874$ for a family consisting of a single parent with two children; it was $\$ 17,463$ for two parents and two children (U.S. Census Bureau 2000a).

\section{Control Variables}

Child and family characteristics are included in the analyses as covariates to control for other factors that may affect enrollment in center-based care and early education. The annual October CPS has a nested structure. Although some family characteristics (such as family household income) are found in the child's record, other information is located in the parent's record. Thus, children's records were matched to those of their parents in order to obtain more detailed family household information.

The child and family household covariates include dichotomous measures of child and family characteristics that prior research suggests influence parents' choice of care arrangements. These characteristics include the following: maternal employment (mother was working during survey week $=1$; not working is the omitted reference category); child's race or ethnicity (three dichotomous indicators: black $=1$, Hispanic $=1$, or

other $=1$; white non-Hispanic is the reference category); child's age (4 years $=1$; 3 years is the reference category); child's gender (boy $=1$; girl is the reference category); family household size (a series of dichotomous indicators for three to seven or more members; two or fewer is the reference category); maternal education (three dichotomous indicators: high school degree $=1$, some college $=1$, college degree $=1$; less than high school degree is the reference category); mother's marital status (married $=1$; not married is the reference category). ${ }^{6}$ Also included is a continuous variable measuring the mother's age in years. Descriptive statistics for child and family household covariates, by income group, are listed in table 2.

State-Level Early Education and Child-Care Funding Variables

Federal and state expenditures on CCDF and TANF are measured using information collected by the Congressional Research Service (Gish 2002). ${ }^{7}$ The fiscal year begins on October 1 of the prior calendar year, so there is a presumed lag in the data, and enrollment in October is linked to subsidy spending in the 12 months prior.

Federal funding for Head Start in each fiscal year is measured using data provided by the Head Start Bureau. Only the federal portion of 
Table 2

Descriptive Statistics by Income Group

\begin{tabular}{|c|c|c|}
\hline & $\begin{array}{l}\text { Low Income } \\
(n=5,784)\end{array}$ & $\begin{array}{l}\text { Higher Income } \\
\quad(n=18,012)\end{array}$ \\
\hline \multicolumn{3}{|l|}{ Child and family household characteristics: } \\
\hline \multicolumn{3}{|l|}{ Child's race or ethnicity (reference group is white): } \\
\hline Hispanic & 28 & 13 \\
\hline Black & 32 & 11 \\
\hline Other race or ethnicity & 6 & 5 \\
\hline Child's gender (boy) & 49 & 51 \\
\hline Child's age ( 4 years old) & 49 & 50 \\
\hline \multicolumn{3}{|l|}{ Maternal education: } \\
\hline Less than high school & 44 & 15 \\
\hline High school & 34 & 31 \\
\hline Some college & 18 & 30 \\
\hline College degree & 4 & 26 \\
\hline Maternal employment & 38 & 61 \\
\hline Mother's age (mean) & 31 & 34 \\
\hline Family size (mean) & 3.68 & 3.79 \\
\hline Mother's marital status (married) & 35 & 81 \\
\hline \multicolumn{3}{|l|}{ State characteristics: } \\
\hline Black population & 13 & 13 \\
\hline Female population over age 16 & 23 & 23 \\
\hline Elderly population (age 65 and over) & 13 & 13 \\
\hline Republicans in the state senate & 45 & 43 \\
\hline Republicans in the state house & 41 & 47 \\
\hline Refundable Earned Income Tax Credit & 7 & 8 \\
\hline Refundable child-care tax credit & 10 & 8 \\
\hline Poverty rate for children under age 6 & 27 & 26 \\
\hline Male unemployment rate & 6.03 & 5.98 \\
\hline Log of state median per capita income (mean) & 10.02 & 10.05 \\
\hline \multicolumn{3}{|l|}{ Welfare policies: } \\
\hline AFDC waiver or TANF implemented & 60 & 62 \\
\hline Benefit level (mean \$) & 852 & 873 \\
\hline
\end{tabular}

NoTE. $-\mathrm{AFDC}=$ Aid to Families with Dependent Children; TANF $=$ Temporary Assistance for Needy Families. Statistics are presented for cases without missing data and are in percentages unless otherwise noted. Low income refers to families with incomes in the bottom $25 \%$ of the family income distribution in the sample; higher income refers to families with incomes in the top $75 \%$ of the distribution.

funding for Head Start is used, because state contributions are not systematically reported. However, local Head Start grantees are expected to contribute 20 percent of operating budget, and some of this money may be provided by state or local governments. Thus, the total amount of Head Start spending exceeds federal funding. The fiscal year for Head Start begins in September, reflecting its adherence to a schoolyear calendar. Hence, children's enrollment in center-based care and early education in October is linked to funding from the prior month and throughout the remainder of the school year.

All funding measures, including those for child-care subsidies and Head Start, are adjusted for inflation (using the consumer price index) 
and for the number of poor children under age 13 in the state (using numbers calculated from the U.S. Census Bureau's annual March CPS). ${ }^{8}$ In addition, spending measures are scaled in $\$ 100$ increments.

In most analyses, all sources of funding are combined into a measure of total early education and child-care funding. Expenditure streams are combined because they are hypothesized to have similar effects and because increases in funding for these programs within states are highly correlated over time $(r=0.83)$. Trends in expenditures are reported in table 1.

Unfortunately, data are not available to track state spending on prekindergarten programs throughout the 1990s. Data collected by Karen Schulman, Helen Blank, and Danielle Ewen (1999) provide information on state prekindergarten spending for 3 years $(1994,1999$, and 2001). Data from these years are used to estimate spending for the intervening years by extrapolating (using real dollars and assuming that increases or decreases over time are averaged over the time period). This process, however, produces rather rough estimates of prekindergarten spending from 1994 to 2000 . Consequently, these data are used only in supplemental analyses that explore whether estimates are likely to be biased by the omission of prekindergarten funding.

\section{State-Level Control Variables}

Because changes in child-care and Head Start spending might be correlated with changes in other state characteristics that might influence preschool enrollment, state demographic, political, and policy characteristics are included as control variables. Descriptive statistics for these variables, by income group, are presented in table 2. A detailed explanation of the sources for these data is provided in the appendix in table A1.

The demographic controls include continuous measures of the log of the state per capita median income, the poverty rate for children under age 6 , and the male unemployment rate. Variables measuring the proportion of the population that is black, elderly (age 65 and older), and female (over age 16) are also included. Finally, two variables measure the political climate of the state: the proportion of Republicans in the state's house and the proportion of Republicans in the state's senate. ${ }^{9}$

Covariates are also included to measure key dimensions of changes in welfare and tax policies designed to promote employment among low-income parents. Prior to 1996, several states were granted waivers, which authorized states to implement policies that were more restrictive than existing federal welfare policies. In 1996, the Personal Responsibility and Work Opportunity Reconciliation Act (PRWORA; U.S. Public Law 104-193) transformed cash entitlements into a temporary safety net 
by requiring recipients to engage in work or work-preparation activities. To capture these changes, the fully specified model includes an indicator for whether the state was granted a federal waiver or implemented TANF, as well as a continuous variable for the level of welfare (AFDC or TANF) and food stamp benefits available to a family of four. The fully specified model also includes indicators for whether the state instituted a refundable Earned Income Tax Credit (EITC) and whether the state had a refundable child-care tax credit. $^{10}$

\section{Methods}

To examine how increases in expenditures for early education and child care are associated with children's enrollment in formal child care, the following equation is estimated:

$$
\operatorname{Pr}\left(\text { Formal care } \text { car }_{i}=1 \mid \beta_{0} \text { Funding }_{j t}+\beta_{1} \boldsymbol{X}_{i j t}+\beta_{2} \text { StateCh }_{j t}\right) .
$$

The probability that child $i$ participates in formal care is modeled as a function of a vector of child and family characteristics $(\boldsymbol{X})$, state $j$ 's early education and child-care funding (Funding), and state $j$ 's characteristics at time $t$ (StateCh). Given the dichotomous dependent variable, probit models are employed. For ease of interpretation, marginal effects are reported rather than coefficients. The marginal effect of the coefficient of interest, $\beta_{0}$, provides an estimate of the association between an additional $\$ 100$ of funding per child and the probability that the child was enrolled in formal care.

Households are enrolled in the CPS study for 2 years. With the exception of 1995 (when the household identification variable changed), households can be linked across years. About 11 percent of children are represented in the data in the same year as a sibling. Altogether, about 49 percent are either enrolled twice or have a sibling represented. To adjust for this nonindependence in the data, all analyses use robust standard errors that are clustered by household.

Analyses are conducted separately for the low- and higher-income samples because the effects of child-care policies should differ for the two groups. Results from three specifications are presented. Predictors in the first model include total funding, child and family characteristics, and a set of year and state dummy variables. The second model adds a set of state characteristics. The third model adds an interaction term (low income by total funding) to test if the estimated difference in the effects of funding for low- and higher-income children is statistically significant.

Additional models are estimated to determine how robust the findings are to alternative specifications, such as including a measure of prekindergarten funding and changing the years from which the sample is drawn. Finally, to explore whether spending has differential effects 
depending on children's age and their mother's marital status, interaction terms (age 4 by spending and married by spending) are included in the regression analyses. As discussed earlier, there may be age differences, such that the enrollment of 3-year-olds was more strongly affected by expenditures, given the higher enrollment levels and much wider availability of low-cost programs (including prekindergarten programs) for 4-year-olds. Differences by marital status are also possible. Compared with married mothers, single-mother families may be more sensitive to child-care costs and also more strongly affected by expansions in child-care subsidies related to welfare reform (although these subsidies would have been available to all low-income families, regardless of marital status).

An advantage of using the CPS microdata is that they include measures of important child and family household characteristics (such as the child's race or ethnicity), which may be related to early education enrollment. Including these variables should help to remove any spurious correlations that may result from changing sample characteristics and from changes in early education funding.

One puzzle is how to handle maternal employment and family household income. If increasing rates of maternal employment or rising family incomes are driving both increases in public expenditures as well as families' use of formal child care, then to isolate the effects of state funding, these confounds should be controlled. However, some (e.g., Powell 1997) argue that maternal employment and child-care decisions are jointly determined, in which case controlling for maternal employment is inappropriate. Although this joint determination is less likely to affect decisions related to early education than decisions related to other types of child care, this consideration nevertheless suggests that neither income nor employment should be included as controls.

The analyses undertaken for this article are conservative in that they include a dichotomous measure of maternal employment. The measure of household income is excluded because inflation makes the categories incomparable over time and because the models include a control for maternal education, which is highly correlated with family household income. Nevertheless, results are not sensitive to the exclusion of maternal employment or the inclusion of a set of income dummy variables (for the categorical levels of family income).

The use of state and year fixed effects is particularly important in this analysis. States with high levels of funding for child care and early education may differ in unobserved ways from states with low levels of funding, and this unobserved heterogeneity may bias estimates. By using state fixed effects, the analyses remove any bias due to persistent unobserved differences across states. Year fixed effects remove bias from trends that are common across states and that are due to unobserved events, including changes in the composition of the low-income pop- 
ulation. Thus, the analysis capitalizes on the large increases in statelevel expenditures by identifying the effects of changes in funding on formal enrollment within states over time.

State and year fixed effects do not control for state characteristics that change over time, and thus, the inclusion of measured state characteristics is also central to the estimation strategy. Because the vast majority of the funding for Head Start and means-tested child-care subsidies comes from the federal government and because increases in spending on early education and child care are largely due to increased federal appropriations, it seems unlikely that changes in state characteristics are correlated with changes in the per child spending measures.

In the period under study, most increases in expenditures for childcare assistance were allocated based on a formula that considered both prior levels of funding and the need for assistance (as proxied by the number of children living in low-income families). In the case of CCDF, a state's federal guaranteed funds are fixed. The amount is based on prior levels of child-care assistance spending under the AFDC program. Federal mandatory (MOE) matching funds are based on the relative share of children under age 13. Disbursements of federal discretionary funds are based on the share of children under age 5 , the share receiving free or reduced-price school lunch, and the state's per capita income (Gish 2002). Prior to the establishment of the CCDF in 1996, discretionary matching funds for child-care assistance were allocated to states using the same three factors. In the case of Head Start, additional funds are allocated across states in proportion to the number of poor children in each state (Butler and Gish 2003; Besharov and Higney 2006). Consequently, spending estimates are adjusted for the number of poor children under age 13, and the analyses include variables that proxy for related state characteristics. These variables include the poverty rate among children under age 6 and the log of the state's per capita median income.

Other state characteristics are included to capture broad demographic shifts that might be related to public funding for child care and early education and to enrollment in formal care. These variables include the proportion of the state population that consists of women over age 16 , the proportion that is black, the proportion that is elderly, and indicators of the political climate (the proportions of the state's house and senate that are Republican). In addition, state policy measures are included as covariates to capture changes in welfare policy during the 1990s.

Analyses ideally would include all state characteristics that are spuriously rather than causally correlated with formal care participation. However, it is difficult to determine which characteristics and demographic trends are exogenous. To the extent that state characteristics included in the models have some direct effects on spending, the models may overcon- 
trol for state factors and bias the estimates of spending downwards. For example, if an increase in the female population over age 16 is linked to increases in formal care because that group effectively advocates for public funding for early education, then models controlling for this variable may underestimate the effects of public funding. If, however, an increase in the population of women over age 16 is also linked to the supply of formal care programs, then omitting this variable from the analyses may result in overstating the effects of spending. Consequently, results are presented from models with and without covariates. This approach places some bounds on the range of possible effects.

Fixed effects methods compare children within a state over time. One concern is having sufficient numbers of observations within a state during each year. Small numbers of observations in a state for a particular year will lead to measurement error. In the analyses for low-income children, sample sizes in some states for some years are very low. ${ }^{11}$ In order to reduce the possibility that associations will be obscured by small sample sizes, the sample is limited to children residing in states in which at least 15 low-income children were observed during at least 2 years. Imposing these criteria reduces the sample from 35,032 to 21,598 and limits the sample to children residing in 26 of the 50 states (see table A2 in the appendix for details on the composition of the sample). ${ }^{12}$

\section{Results}

Trends in funding (presented in table 1) suggest that, for the most part, levels of early childhood education and care funding have increased steadily. ${ }^{13}$ Total federal funding for early education and care (per poor child under age 13) appears to have nearly tripled. Prior to 1996, per child funding increased at a roughly similar rate for both child-care subsidies and Head Start. Beginning in 1997, however, funding for childcare subsidies grew at a higher rate than funding for Head Start. Subsidy funding accounted for about one-half of total funding in 1992 but for over two-thirds by 2000.

Mean levels of formal care enrollment also show strong upward trends from 1992 to 2000 among both low-income and higher-income children (table 1), although year-to-year changes in enrollment and funding are not always positive. Low-income children remain less likely than their higher-income peers to be enrolled in formal care. However, the gains in enrollment over this period appear larger for low-income children than for their higher-income counterparts (over 16 percentage points compared with 8 percentage points).${ }^{14}$ Because of the eligibility guidelines, early education and care funding should be positively associated with low-income children's enrollment in formal care but should not be associated with the enrollment of higher-income children. The large increase in early education and care funding, coupled with a relatively 
Table 3

Effects of Public Funding on Formal Care Enrollment

\begin{tabular}{|c|c|c|c|c|c|c|c|c|}
\hline & \multicolumn{4}{|c|}{$\begin{array}{c}\text { Low-InCome SAmple, } \\
\text { Formal Care EnRollment }\end{array}$} & \multicolumn{4}{|c|}{$\begin{array}{l}\text { Higher-InCome SAmple, } \\
\text { Formal CARE ENRollment }\end{array}$} \\
\hline & $\begin{array}{l}\text { Model 1: } \\
\text { Fixed Eff }\end{array}$ & $\begin{array}{l}\text { State } \\
\text { fects }\end{array}$ & \multicolumn{2}{|c|}{$\begin{array}{l}\text { Model 2: State } \\
\text { Fixed Effects } \\
\text { Plus State } \\
\text { Characteristics } \\
\text { and Policies } \\
\end{array}$} & $\begin{array}{l}\text { Model 1: } \\
\text { Fixed Eff }\end{array}$ & $\begin{array}{l}\text { State } \\
\text { ects }\end{array}$ & \multicolumn{2}{|c|}{$\begin{array}{l}\text { Model 2: State } \\
\text { Fixed Effects } \\
\text { Plus State } \\
\text { Characteristics } \\
\text { and Policies }\end{array}$} \\
\hline & $\begin{array}{l}\text { Marginal } \\
\text { Effect }\end{array}$ & $\mathrm{SE}$ & $\begin{array}{l}\text { Marginal } \\
\text { Effect }\end{array}$ & $\mathrm{SE}$ & $\begin{array}{c}\text { Marginal } \\
\text { Effect }\end{array}$ & $\mathrm{SE}$ & $\begin{array}{c}\text { Marginal } \\
\text { Effect }\end{array}$ & $\mathrm{SE}$ \\
\hline Total funding & $.013 *$ & .006 & $.018^{*}$ & .008 & -.001 & .003 & .004 & .004 \\
\hline \multicolumn{9}{|l|}{$\begin{array}{l}\text { Child's race or ethnicity } \\
\text { (white is reference): }\end{array}$} \\
\hline Hispanic & -.042 & .022 & -.043 & .022 & $-.105^{* *}$ & .015 & $-.104^{* *}$ & .015 \\
\hline Black & $.079 * *$ & .021 & $.078 * *$ & .021 & $.056^{* * *}$ & .015 & $.055^{* *}$ & .015 \\
\hline \multicolumn{9}{|l|}{$\begin{array}{l}\text { Maternal education } \\
\text { (high school is } \\
\text { reference): }\end{array}$} \\
\hline High school degree & .036 & .019 & .036 & .019 & $.043 * *$ & .016 & $.043^{* * *}$ & .016 \\
\hline Some college & $.112 * *$ & .023 & $.112 * *$ & .023 & $.139 * *$ & .016 & $.140 * *$ & .016 \\
\hline College degree & $.133 * *$ & .041 & $.136^{* * *}$ & .040 & $.259 * *$ & .016 & $.260^{* * *}$ & .016 \\
\hline Maternal employment & $.063 * *$ & .016 & $.062 * *$ & .016 & $.033 * *$ & .009 & $.032^{* * *}$ & .009 \\
\hline \multicolumn{9}{|l|}{ Year: } \\
\hline 1993 & .024 & .028 & $-.190^{*}$ & .079 & .012 & .016 & .014 & .059 \\
\hline 1994 & $.109 * *$ & .041 & $-.260 * *$ & .089 & $-.109 * *$ & .036 & -.113 & .078 \\
\hline 1995 & $.071 *$ & .030 & $-.263 * *$ & .101 & $.084^{* * *}$ & .017 & .087 & .087 \\
\hline 1996 & .058 & .032 & $-.314 * *$ & .100 & $.113^{* * *}$ & .018 & .129 & .104 \\
\hline 1997 & $.143 * *$ & .035 & $-.299 *$ & .118 & $.123 * *$ & .019 & .140 & .118 \\
\hline 1998 & $.099 *$ & .042 & $-.363^{* * *}$ & .096 & $.124 * *$ & .022 & .140 & .140 \\
\hline 1999 & .070 & .047 & $-.401 * *$ & .087 & $.147 * *$ & .025 & .161 & .152 \\
\hline 2000 & .082 & .057 & $-.409 * *$ & .066 & $-.110 * *$ & .031 & .117 & .170 \\
\hline$R^{2}$ & .12 & & .13 & & .11 & & .11 & \\
\hline$N$ & \multicolumn{4}{|c|}{5,386} & \multicolumn{4}{|c|}{16,212} \\
\hline
\end{tabular}

Note. - Table shows marginal effects and standard errors from probit regression models. Models 1 and 2 contain a full set of child and family covariates listed in table 2, as well as state and year fixed effects. Model 2 also contains the full set of state characteristics and welfare policy variables listed in table 2 . Low income refers to families with incomes in the bottom $25 \%$ of the distribution for family incomes in the sample; higher income refers to families with incomes in the remaining $75 \%$ of the distribution.

$* p \leq .05$.

** $p \leq .01$.

large increase in enrollment among low-income children, provides preliminary evidence that public funding might have promoted enrollment in formal care for low-income children.

Multivariate regressions are estimated separately for the low- and higher-income children in the sample. The first four columns of table 3 present results from analyses regarding low-income children. The last four columns present results from analyses regarding higher-income children. Findings suggest that public funding for formal care is positively and significantly associated with low-income children's enrollment. An additional $\$ 100$ of funding per poor child under age 13 is associated with an increase in the enrollment rate in formal care of more than 1 
percentage point (from the base rate of 41 percent).$^{15}$ Public funding increased by about $\$ 800$ per child from 1992 to 2000 . This suggests that funding expansions may account for 9.6 of the 16 percentage point gain in low-income children's enrollment in formal child care.

Results from model 2 suggest that the effect of state spending is slightly larger when state characteristics are taken into account. The estimated effect from model 2 translates into a 1.8 percentage point increase in enrollment per $\$ 100$ increase in early education funding. ${ }^{16}$ Given the size of the funding increase, this estimate indicates that expansions in public funding for formal care might account for as much as 14 of the 16 percentage point enrollment gain among low-income children from 1992 to 2000.

In addition, results in model 2 indicate that the coefficients for the year dummy variables are negative. These negative coefficients result from including the measure of log state per capita median income, which is positively related to enrollment in formal child care and increases over time. ${ }^{17}$ Removing this variable from the analysis yields coefficients for the year variables that are not statistically significant. This suggests that, in a multivariate analysis, there is no clear time trend in enrollment.

Results in table 3 show that public funding for formal care has no discernable effect on the formal care enrollment of higher-income children. Results also suggest that the coefficients for several child and family characteristics differ across the low- and higher-income populations. For example, among those with higher incomes, college-educated mothers are more likely than less educated mothers to place their children in formal child care. In the low-income sample, employed mothers are more likely than nonemployed mothers to place their children in formal child care. These differences suggest that formal care selection processes may depend on family's socioeconomic resources.

To formally test whether the effects of early education and child-care spending for low-income children differ from those for higher-income children, regressions are estimated with an interaction term (spending by low income). The results indicate that the estimated associations between funding and formal care enrollment are significantly larger among low-income children. The difference in the estimated effects of funding is about $0.006(p<.05)$, suggesting that, at 0.012 , the overall effects of funding are twice as large among low-income children as they are among higher-income children (results not shown). ${ }^{18}$

To check the robustness of the results, a set of similar analyses are conducted, varying the years under consideration and the sources of support included in the funding measure. First, to examine possible differences in the years before and after welfare reform (when childcare funding mechanisms and the data source for TANF expenditures differed), models were estimated separately for these years. Although 
Table 4

Effects of Public Funding on Formal Care Enrollment: Results from Alternative Specifications

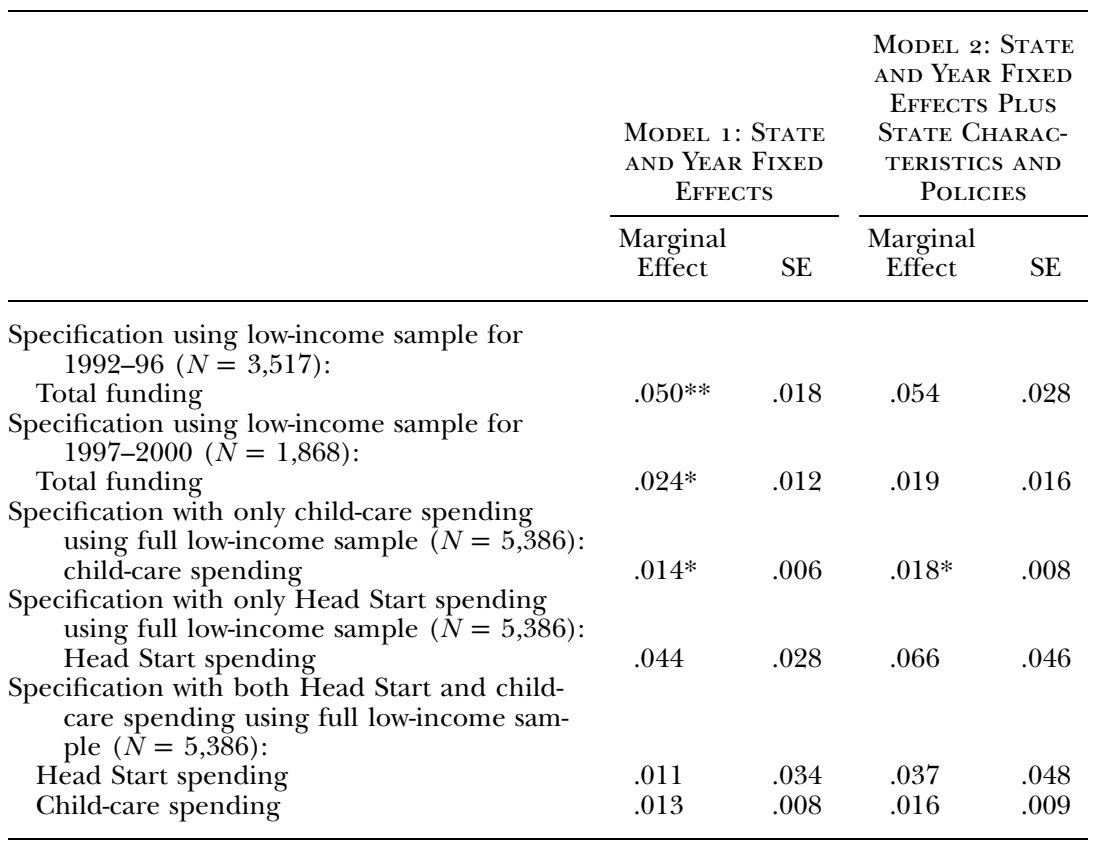

Note. - Table shows marginal effects and standard errors from probit regression models. Models 1 and 2 contain the full set of child and family covariates listed in table 2, as well as state and year fixed effects. Model 2 also contains the full set of state characteristics and welfare policy variables listed in table 2 . Low income refers to families with incomes in the bottom $25 \%$ of the distribution for family incomes in the sample.

$* p \leq .05$.

*** $p \leq .01$.

the estimates in equations for the early (1992-96) and later (1997-2000) years are as large as those for the entire time period, the association between funding and enrollment in formal care appears to be somewhat larger prior to 1997 (see table 4). The coefficients suggest that, between 1992 and 1996, an additional $\$ 100$ resulted in a more than 5 percentage point increase in enrollment. Separate analyses (not shown) find similar results for this period if only child-care subsidy spending was included.

Another issue is whether the effects of Head Start and child-care assistance differ from each other. Increases in spending on both programs should have boosted children's enrollment in formal child care, and as noted earlier, spending on the programs is highly correlated within states over time. Nevertheless, the programs operate in different ways, and this may lead to differential effects. To explore this, each type of funding is entered separately into regressions (as reported in table 
4). Results from these analyses suggest that the magnitude of the associations between child-care subsidy funding (welfare and CCDF monies) and enrollment mirrors prior findings for total child-care funding. The coefficients for Head Start expenditures are larger than those associated with subsidies, but standard errors are also large. This pattern of effects is also found when both child care and Head Start were entered jointly into a regression. A Wald test indicates that the estimated effects of the two funding variables are not significantly different $\left(\chi^{2}=0.12\right.$, $p=.75)$. These results indicate that it is appropriate to combine these streams to measure total funding.

When entered alone, Head Start funding does not significantly predict formal care enrollment. This finding is not surprising, because Head Start eligibility is restricted to children from families with incomes below the poverty threshold, whereas the low-income sample used here includes a broader sample of families (those from the lowest quartile of family income). When the sample is limited to children in the bottom 20 percent of the income distribution, results suggest that Head Start funding is statistically significantly associated with formal care enrollment (results not shown). ${ }^{19}$

Although the low-income category is designed to roughly match the families that were eligible for some form of child-care assistance during the 1990s, further analyses are conducted to determine whether findings are sensitive to alternative definitions of the low-income population. These further analyses maintain the inclusion criteria of having at least 15 low-income children in each state and year. Consequently, in conducting these analyses, a more generous definition of low income (bottom 30 percent of the income distribution) results in a larger sample of low-income children; a more restrictive definition (bottom 20 percent of the income distribution) results in a smaller sample. Results do not differ substantially when analyses are conducted with different definitions of low income, although the effects of funding on formal care are slightly more pronounced among children in the bottom 20 percent of the income distribution $(0.02, p<.05)$ than among those in the bottom 30 percent of the distribution $(0.012, p<.05)$.

In addition, to check whether the addition of a question prompt in the 1994 October CPS influences the results, models were estimated in which analyses are limited to years when respondents were surveyed with the exact same item (1994-2000). Again, results are robust to this specification (results not shown).

Another issue is whether the effects of spending on enrollment for low-income children differ by the child's age and the mother's marital status. Enrollment rates of low-income 3-year-olds were much lower than those of 4-year-olds. In part, this perhaps reflects the greater availability of formal child-care programs for older children. From 1992 to 2000, 
Table 5

Variation in Effects of Public Funding on Formal Care Enrollment by Child Age and Mother's Marital Status

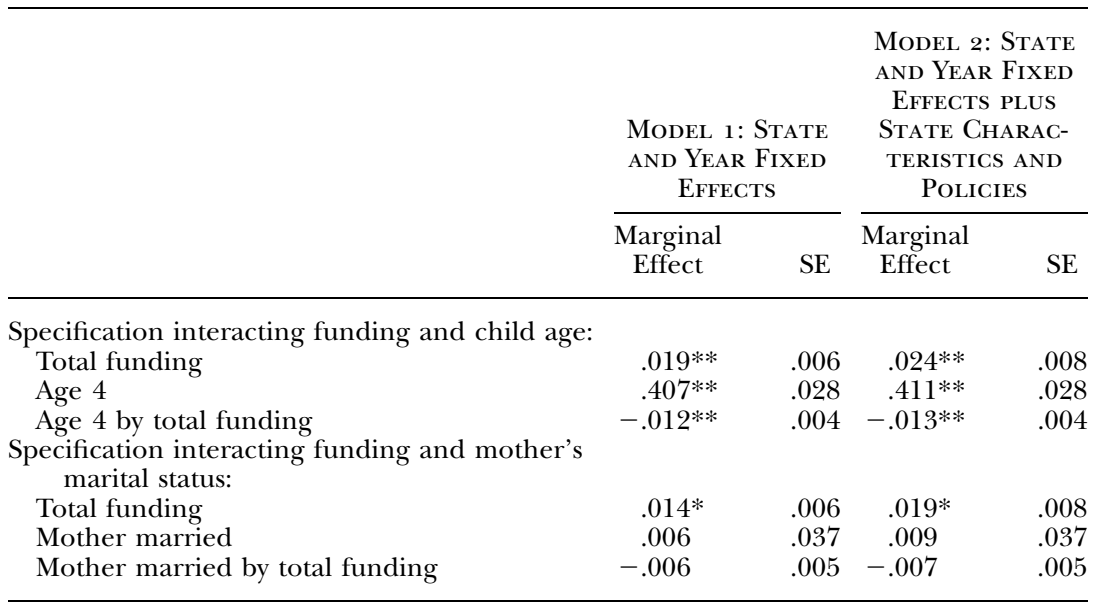

NoTE. - Table shows marginal effects and standard errors from probit regression models Models 1 and 2 contain the full set of child and family covariates listed in table 2 and state and year fixed effects. Model 2 also contains the full set of state characteristics and welfare policy variables listed in table 2 . Sample is the full low-income sample $(N=$ $5,386)$.

$* p \leq .05$.

$* * p \leq .01$.

3-year-olds' enrollment increased from 17 to 35 percent in the sample, while 4-year-olds' enrollment increased from 48 to 63 percent. Results from the interaction analyses suggest that each $\$ 100$ increase in childcare subsidies has less effect on the enrollment of 4-year-old children (0.008) than it does on the enrollment of 3-year-old children (0.024; see table 5, model 2). Thus, increasing public funding for child-care subsidies and Head Start might be most effective in boosting the formal care enrollment of children under the age of 4 .

Increased state spending on prekindergarten programs, which primarily target 4-year-olds, are not included in the primary measure of total funding. This omission may influence the findings. Among the states included in the sample, state spending on prekindergarten rose in 1994 from about $\$ 59$ per poor child under age 13 to about $\$ 183$ in 2000. The robustness of results is checked by adding estimated state prekindgergarten expenditures to the measure of total public funding. Results from regression analyses with a full set of controls suggest that the effects of total public funding, including prekindergarten (results not shown; $0.014, p=.07)$, are remarkably similar to the effects found for the combined measure of Head Start and child-care subsidies (0.014, 
$p<.05$; table 3$).{ }^{20}$ The coefficient is less precisely estimated, however, reflecting that there are fewer years of data and that extrapolation is used to determine prekindergarten spending for several years.

Because state prekindergarten initiatives primarily serve 4-year-old children, analyses also consider whether including prekindergarten funding alters the pattern of results by child age. Results from regressions that include interaction terms for total funding (prekindergarten and children's age) yield no evidence that public support is differentially predictive of 3- or 4-year-olds' formal care enrollment. These findings suggest that child-care subsidies and Head Start may be more strongly linked to enrollment among 3-year-olds than among 4-year-olds, whereas prekindergarten spending boosts the enrollment of 4-year-olds more than that of 3-year-olds. Indeed, regressions in which prekindergarten spending (only) is interacted with the child's age provide some hint that prekindergarten spending is more highly linked with formal care enrollment among 4-year-olds than it is among 3-year-olds. ${ }^{21}$

With regard to differences by marital status, just over one-third of the mothers of low-income children in the sample were married. In the early 1990s, rates of enrollment in formal care among low-income children differed by the mother's marital status. In 1992, married mothers were slightly less likely than their unmarried counterparts to have children who experienced formal care (28 percent vs. 34 percent). However by 2000 , this gap slightly increased; formal care was experienced by only 40 percent of children of married mothers. By contrast, nearly 50 percent of children of single mothers experienced formal care. Results from analyses do not provide strong evidence that the effects of child-care subsidies are lower among married mothers than among their single counterparts, although the estimate is in the expected direction (see table 5).

A final concern is the composition of the sample. Although the choice of 15 for the minimum number of low-income observations for a state and year was somewhat arbitrary, analyses indicate that estimates were not sensitive to using larger (e.g., 20 or 30 low-income observations per state and year) or slightly smaller (e.g., 13 or 14 low-income observations per state and year) alternative cutoffs. This increases confidence that the findings are not an artifact of the choice of sample size cutoffs.

A minimum of 15 observations of poor children for each state and year is used in order to reduce measurement error, but doing so restricts the analyses to states with large populations. It is possible to include children residing in smaller states in regressions that do not include state fixed effects. These analyses use differences across states and over time to identify the effects of funding. If the state fixed effects are removed from the regression, but the same sample of children residing in large states is maintained, total funding is associated with an estimated $0.024(p<.05)$ increase in the probability of enrollment. However, when 
the children residing in small states are included in this analysis, the association is much smaller $(0.008, p<.05)$. If analyses consider only those children who reside in small states, funding is not associated with these children's enrollment $(-0.002, p=.62)$. If comparing the enrollment rates of children across states provides a meaningful picture of how increases in funding influence center-based child-care and early education enrollment, then these findings may indicate that increases in funding may not affect the probability that children residing in smaller states are enrolled in formal care. However, as discussed, this approach may not be appropriate because of the omission of controls for differences across states.

\section{Discussion}

The main focus of this article is whether the increases in public funding for early education and child care in the 1990s resulted in higher levels of formal care enrollment among low-income 3- and 4-year-olds. The results suggest that expansions to public funding increased the probability that a child was enrolled in center-based care and early education programs over this period. The magnitude of the estimated effects indicate that increased funding accounts for between 8 and 11 percentage points of the 16 percentage point increase in low-income children's enrollment. These estimates are robust to the inclusion of measures of state characteristics that may be correlated with child-care and early education funding and enrollment.

In contrast, results suggest that increased public funding for childcare subsidies and Head Start has little association with the use of formal care among higher-income children. Nevertheless, the probability that higher-income children were enrolled in formal care during the preschool years also appears to have increased between 1992 and 2000. This suggests that, in the absence of expanded public support for early education and child care, income-related disparities in enrollment may have widened.

In order to isolate the effects of spending, analyses employ state fixedeffects models that rely on increases in spending within states over time. This approach rules out many alternative hypotheses for the findings, increasing confidence that the estimated effects may be causal. However, in order to estimate models that identify the effects of increases in funding within states over time, analyses must be limited to children residing in relatively large states. Although sensitivity analyses with state fixed-effects models suggest that the findings are not contingent on the particular definition of a large state, once the state fixed effects are removed from the models, analyses provide some evidence that the results may not hold for children residing in small states. Consequently, the findings should only be generalized to large states, and future re- 
search should consider the association between public funding and formal care enrollment in small states.

The estimated effects of funding on enrollment in formal care are greater between 1992 and 1996 than between 1997 and 2000. One possible explanation for the difference is the growth in the later period of unconstrained subsidies, which can be used for informal as well as formal care. A similar period effect is observed if only subsidy funding is analyzed. This finding suggests that states may have changed subsidy policies and administrative practices in the late 1990s. The increased emphasis on rapid employment for welfare-recipient families, for example, may have increased parents' need for (and welfare agencies' encouragement of) the use of subsidies to purchase informal arrangements. For parents exiting welfare, such arrangements were both more readily available and less costly than formal child-care arrangements. Head Start program enhancements, including the expansion from part- to full-day services, may also have diluted the effect of funding increases on the creation of new enrollment slots during the 1990s. It is also possible that child-care subsidy expenditures are measured with more error after the transition to TANF because guidelines allow states to report the same funds as MOE spending for both TANF and CCDF; if so, the resulting measurement error would bias the estimates toward zero.

The estimated effects of child-care subsidy and Head Start funding are larger for 3-year-olds than for 4-year-olds. However, the analyses of state prekindergarten spending indicate that this pattern (larger effects for 3-year-olds) may be offset by some increases in state prekindergarten funding for 4-year-olds. Indeed, it may be that increased availability of prekindergarten for some 4-year-olds reduces the role that child-care subsidies and Head Start play in promoting enrollment in early education among this age group. Future research, with improved data on prekindergarten spending, is necessary to more carefully evaluate this possibility.

If the probability of enrolling in formal care increases by 1 to 2 percentage points with an increase of $\$ 100$ in funding per poor child under age 13, is that a large effect? An association of this magnitude suggests that over half of the increase in low-income children's enrollment in formal care in the 1990s may be explained by increases in public early education and child-care funding. In that sense, such an increase may be considered a large effect. But should an even larger increase in enrollment be expected from a 300 percent increase in available funding (per poor child under age 13)? The answer is not straightforward. First, parents' choice of child care is not solely determined by price. There are many other concerns, such as convenience or consonance of the care with their work schedule and values, that parents take into account when making child-care decisions (Lowe and Weisner 2004; Meyers and Jordan 2006). Rising rates of maternal employment and nonstandard- 
hours employment, particularly among low-income mothers in the late 1990s, may have altered the attractiveness or feasibility of formal care relative to informal forms of care.

Second, the analyses consider the enrollment of children in formal care only. Over half of funding during this period was provided in the form of unconstrained subsidies, and such funding grew at a much faster rate than funding specifically designated for early education. Unconstrained subsidies can be used for both informal and formal child care, and state policies and administrative procedures (such as reimbursement rates and copayment schedules) may divert parents toward less costly forms of informal care (Meyers et al. 2002). Total public spending per poor child is still well below the cost of full-time center-based care or preschool. Indeed, even after the funding increases in the 1990s, federal sources allocate only $\$ 1,200$ per poor child under age 13 . As a result, only a fraction of low-income children have access to full-time center-based care. Some states ration this assistance by limiting the number of families served. Only an estimated 15 percent of income-eligible children received assistance through means-tested subsidy programs in the late 1990s, and many states maintained waiting lists for assistance during the period examined here (Blank et al. 1999). Other states ration assistance through policies (such as high family copayments and low reimbursements to providers) that discourage families from using formal care arrangements, which are often more expensive than other forms of care.

Finally, the analyses only consider whether a child participates in center-based care or an early education program. The analyses cannot determine whether increases in funding alter the intensity of children's participation in formal care (in terms of the number of months or hours that children attend these programs) or the quality of care children experience. Further investigation of this issue is complicated because of the data limitations discussed previously, but the issue is an important topic for future research.

Because findings suggest that expansions in child-care and early education funding increase enrollment in formal care among low-income children but not higher-income children, the analyses provide evidence that the gaps in enrollment between low- and higher-income children might have been larger in the absence of the funding increases. It follows, then, that further expansions may be effective in increasing the formal care enrollment of low-income children and in closing persistent gaps in enrollment between children from low- and higher-income families. Indeed, when the costs of early education and center-based child care were reduced for low-income families in the 1990s, more children experienced formal care.

However, the structure of funding also may affect enrollment. Although unconstrained child-care subsidies afford parents the maximum 
degree of choice over the selection of child-care arrangements, subsidies may be a weaker tool for reducing gaps in formal care enrollment than investments directly targeting the expansion of the supply of free or affordable early education services. In addition, the equalizing effects of subsidies on enrollment gaps will be weaker still if state policies and administrative practices discourage the use of these subsidies for early education arrangements that cost more than informal arrangements.

Several limitations to this study should be noted. First, because the analyses are limited to states with large populations of children, the results may not generalize to states with smaller populations of children. It would be valuable to conduct similar analyses with a data set that has large samples of low-income children in at least some smaller states. Second, it is not possible to estimate precisely the links between all sources of increases in early education funding and formal care enrollment. In particular, data constraints hamper the estimation of the role of local school-district and state prekindergarten expenditures. The investigation of prekindergarten, however, indicates that omitting this source of funding from the main estimates does not bias estimates of the effects of Head Start and child-care subsidies on center-based care and early education enrollment.

Finally, the analyses do not prove that increases in expenditures for early education caused increases in low-income children's enrollment. Rather, the analyses show evidence of a strong link between increases in funding and enrollment within states over time. Given that early education is not currently an entitlement and that child-care subsidy assistance continues to be rationed (formally and informally), the availability of assistance is likely to be exogenous to the child-care decisions of individual families at a point in time. Thus, it is reasonable to conclude that changes in enrollment in any given year are most likely due to expenditures rather than the reverse (i.e., that changes in enrollment determined public expenditures).

It is possible, however, that other unmeasured changes in state characteristics and policies may bias the estimates. To reduce this possibility, analyses include changes in important policies that have been credited with increasing maternal employment during this period. These changes include the introduction of welfare waivers, PRWORA, and state Earned Income Tax Credits. Analyses also include measures of key state characteristics (such as the unemployment rate, percent of young children under age 6 in poverty, and per capita income) that might be linked to changes in funding. Including these covariates does not diminish the estimated effects of public funding for early education and child care.

This study points to several important issues for future research. First, the variation across states in how child-care subsidies are structured suggests that future work might consider not only how funding affects the use of formal care but also how increased funding may interact with 
other child-care and early education policies. Will more children enter formal care if additional funding is used to reduce parent copayment rates? Will more children enter care if policies increase the number of families receiving assistance or raise the reimbursement rates for providers? The answers to these types of questions may provide valuable information to guide policy decisions.

As the discussion noted earlier, the current analyses cannot measure the amount of time that children spend in formal care or the quality of the programs that children attend, nor can they track changes in enrollment in other types of child care. Ultimately, in order to assess the importance of the enrollment changes documented here, it is important to know something about each of these outcomes. For example, it is important to understand the quality of the programs and hours of attendance relative to what children otherwise would experience. Future research should also look at the implications of these enrollment changes for children's school readiness and families' economic wellbeing. All of these are important directions for future research. 


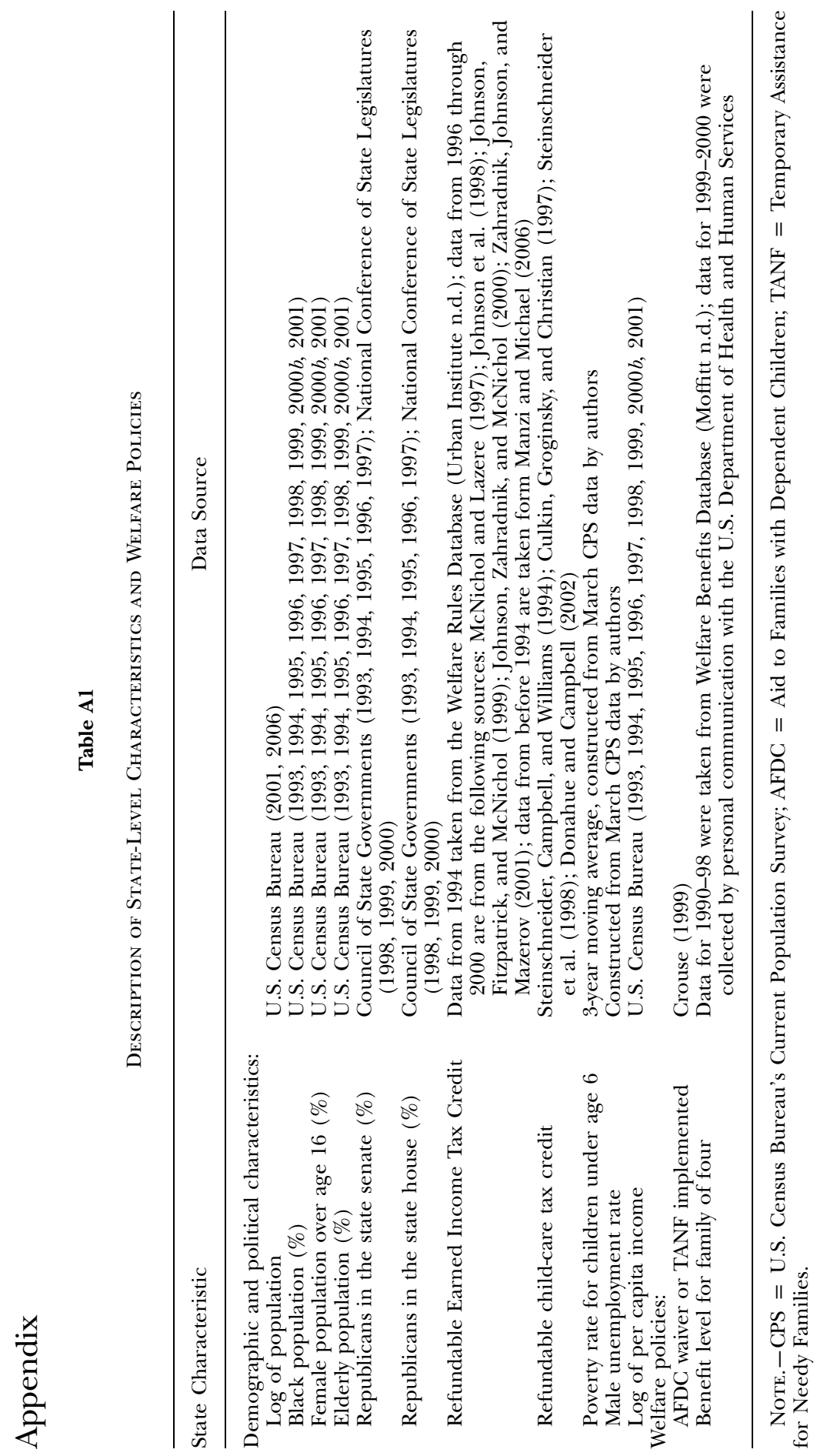


Table A2

SAmple Composition by State and Year

\begin{tabular}{|c|c|c|c|c|c|c|c|c|c|c|c|}
\hline State & 1992 & 1993 & 1994 & 1995 & 1996 & 1997 & 1998 & 1999 & 2000 & $\begin{array}{c}\text { Low- } \\
\text { Income } \\
N\end{array}$ & $\begin{array}{c}\text { Higher- } \\
\text { Income } \\
\quad N\end{array}$ \\
\hline Alabama & $\mathrm{X}$ & $\mathrm{X}$ & $\mathrm{X}$ & & & $\mathrm{X}$ & $\mathrm{X}$ & $\mathrm{X}$ & $\mathrm{X}$ & 110 & 209 \\
\hline Arizona & & $\mathrm{X}$ & $\mathrm{X}$ & $\mathrm{X}$ & $\mathrm{X}$ & $\mathrm{X}$ & $\mathrm{X}$ & $\mathrm{X}$ & & 85 & 226 \\
\hline Arkansas & $\mathrm{X}$ & $\mathrm{X}$ & $\mathrm{X}$ & $\mathrm{X}$ & $\mathrm{X}$ & $\mathrm{X}$ & $\mathrm{X}$ & $\mathrm{X}$ & & 91 & 180 \\
\hline California & $\mathrm{X}$ & $\mathrm{X}$ & $\mathrm{X}$ & $\mathrm{X}$ & $\mathrm{X}$ & $\mathrm{X}$ & $\mathrm{X}$ & $\mathrm{X}$ & $\mathrm{X}$ & 850 & 2,497 \\
\hline Florida & $\mathrm{X}$ & $\mathrm{X}$ & $\mathrm{X}$ & $\mathrm{X}$ & $\mathrm{X}$ & $\mathrm{X}$ & $\mathrm{X}$ & $\mathrm{X}$ & $\mathrm{X}$ & 351 & 1,108 \\
\hline Georgia & $\mathrm{X}$ & $\mathrm{X}$ & $\mathrm{X}$ & & $\mathrm{X}$ & $\mathrm{X}$ & $\mathrm{X}$ & $\mathrm{X}$ & $\mathrm{X}$ & 121 & 310 \\
\hline Idaho & & & $\mathrm{X}$ & $\mathrm{X}$ & $\mathrm{X}$ & $\mathrm{X}$ & $\mathrm{X}$ & $\mathrm{X}$ & $\mathrm{X}$ & 112 & 281 \\
\hline Illinois & $\mathrm{X}$ & $\mathrm{X}$ & $\mathrm{X}$ & $\mathrm{X}$ & $\mathrm{X}$ & $\mathrm{X}$ & $\mathrm{X}$ & $\mathrm{X}$ & $\mathrm{X}$ & 315 & 1,172 \\
\hline Kentucky & $\mathrm{X}$ & $\mathrm{X}$ & $\mathrm{X}$ & & & & & & & 59 & 91 \\
\hline Louisiana & $\mathrm{X}$ & $\mathrm{X}$ & $\mathrm{X}$ & $\mathrm{X}$ & $\mathrm{X}$ & $\mathrm{X}$ & $\mathrm{X}$ & $\mathrm{X}$ & & 108 & 184 \\
\hline Massachusetts & $\mathrm{X}$ & $\mathrm{X}$ & $\mathrm{X}$ & $\mathrm{X}$ & $\mathrm{X}$ & & & & & 136 & 586 \\
\hline Michigan & $\mathrm{X}$ & $\mathrm{X}$ & $\mathrm{X}$ & $\mathrm{X}$ & $\mathrm{X}$ & $\mathrm{X}$ & $\mathrm{X}$ & $\mathrm{X}$ & $\mathrm{X}$ & 332 & 1,057 \\
\hline Mississippi & $\mathrm{X}$ & $\mathrm{X}$ & $\mathrm{X}$ & $\mathrm{X}$ & $\mathrm{X}$ & $\mathrm{X}$ & $\mathrm{X}$ & $\mathrm{X}$ & & 164 & 293 \\
\hline Montana & & $\mathrm{X}$ & $\mathrm{X}$ & & & & & & $\mathrm{X}$ & 51 & 115 \\
\hline Nebraska & & $\mathrm{X}$ & & $\mathrm{X}$ & & & & & & 33 & 84 \\
\hline New Jersey & $\mathrm{X}$ & $\mathrm{X}$ & $\mathrm{X}$ & $\mathrm{X}$ & $\mathrm{X}$ & $\mathrm{X}$ & & & & 129 & 798 \\
\hline New Mexico & $\mathrm{X}$ & $\mathrm{X}$ & $\mathrm{X}$ & $\mathrm{X}$ & $\mathrm{X}$ & $\mathrm{X}$ & $\mathrm{X}$ & $\mathrm{X}$ & & 194 & 293 \\
\hline New York & $\mathrm{X}$ & $\mathrm{X}$ & $\mathrm{X}$ & $\mathrm{X}$ & $\mathrm{X}$ & $\mathrm{X}$ & $\mathrm{X}$ & $\mathrm{X}$ & $\mathrm{X}$ & 553 & 1,782 \\
\hline North Carolina & $\mathrm{X}$ & $\mathrm{X}$ & $\mathrm{X}$ & $\mathrm{X}$ & $\mathrm{X}$ & $\mathrm{X}$ & $\mathrm{X}$ & $\mathrm{X}$ & $\mathrm{X}$ & 269 & 804 \\
\hline Ohio & $\mathrm{X}$ & $\mathrm{X}$ & $\mathrm{X}$ & $\mathrm{X}$ & $\mathrm{X}$ & $\mathrm{X}$ & $\mathrm{X}$ & $\mathrm{X}$ & $\mathrm{X}$ & 324 & 1,148 \\
\hline Oklahoma & & & $\mathrm{X}$ & & $\mathrm{X}$ & & & $\mathrm{X}$ & & 54 & 140 \\
\hline Pennsylvania & $\mathrm{X}$ & $\mathrm{X}$ & $\mathrm{X}$ & $\mathrm{X}$ & $\mathrm{X}$ & $\mathrm{X}$ & $\mathrm{X}$ & $\mathrm{X}$ & $\mathrm{X}$ & 245 & 1,130 \\
\hline South Dakota & & $\mathrm{X}$ & $\mathrm{X}$ & $\mathrm{X}$ & & & & & & 59 & 161 \\
\hline Tennessee & $\mathrm{X}$ & $\mathrm{X}$ & $\mathrm{X}$ & & & & & & & 53 & 115 \\
\hline Texas & $\mathrm{X}$ & $\mathrm{X}$ & $\mathrm{X}$ & $\mathrm{X}$ & $\mathrm{X}$ & $\mathrm{X}$ & $\mathrm{X}$ & $\mathrm{X}$ & $\mathrm{X}$ & 519 & 1,320 \\
\hline West Virginia & $\mathrm{X}$ & & $\mathrm{X}$ & $\mathrm{X}$ & & & & $\mathrm{X}$ & & 69 & 128 \\
\hline Total & & & & & & & & & & 5,386 & 16,212 \\
\hline
\end{tabular}

NotE. - The sample is restricted to years in which the data from the U.S. Census Bureau's Current Population Survey have at least 15 low-income children in a particular state. Low income refers to families with incomes in the bottom $25 \%$ of the distribution for family incomes in the sample; higher income refers to families with incomes in the remaining $75 \%$ of the distribution. 


\section{Social Service Review}

Table A3

Formal Care Enrollment and Public Funding per Child, 1992-2000: 50-STate SAmple

\begin{tabular}{|c|c|c|c|c|c|c|}
\hline Year & $\begin{array}{c}\text { Low-Income } \\
\text { Enrollment } \\
(\%)\end{array}$ & $\begin{array}{c}\text { Higher-Income } \\
\text { Enrollment } \\
(\%)\end{array}$ & $\begin{array}{l}\text { Gap } \\
(\%)\end{array}$ & $\begin{array}{c}\text { Total } \\
\text { Funding } \\
(\$)\end{array}$ & $\begin{array}{c}\text { Child-Care } \\
\text { Subsidies } \\
\qquad \$)\end{array}$ & $\begin{array}{c}\text { Head } \\
\text { Start } \\
(\$)\end{array}$ \\
\hline 1992 & 31.95 & 43.16 & 11.21 & 4.75 & 2.62 & 2.13 \\
\hline 1993 & 32.79 & 42.67 & 9.88 & 5.14 & 2.67 & 2.47 \\
\hline 1994 & 41.64 & 49.27 & 7.63 & 5.70 & 2.85 & 2.85 \\
\hline 1995 & 40.96 & 51.05 & 10.09 & 6.14 & 3.20 & 2.94 \\
\hline 1996 & 39.14 & 50.46 & 11.32 & 6.17 & 3.21 & 2.96 \\
\hline 1997 & 47.40 & 53.61 & 6.21 & 7.10 & 3.94 & 3.16 \\
\hline 1998 & 42.41 & 53.65 & 11.24 & 9.02 & 5.50 & 3.52 \\
\hline 1999 & 46.20 & 56.60 & 10.4 & 10.98 & 7.15 & 3.83 \\
\hline 2000 & 46.98 & 53.73 & 6.75 & 13.30 & 9.03 & 4.27 \\
\hline $\begin{array}{l}\text { Increase in } \\
\text { enrollment, } \\
\text { 1992-2000 }\end{array}$ & 15.03 & 10.57 & NA & NA & NA & NA \\
\hline $\begin{array}{l}\text { Increase in } \\
\text { funding, } \\
\text { 1992-2000 }\end{array}$ & NA & NA & NA & 8.55 & 6.41 & 2.14 \\
\hline
\end{tabular}

Note. $-\mathrm{NA}=$ not applicable. All amounts (total funding, child-care subsidies, and Head Start) have been adjusted for inflation using the consumer price index and divided by the number of poor children under age 13 in a state. Low income refers to families with incomes in the bottom $25 \%$ of the family income distribution in the sample; high income refers to families with incomes in the top $75 \%$ of the distribution.

\section{References}

$\rightarrow$ Adams, Gina, and Monica Rohacek. 2002. "More than Work Support? Issues around Integrating Child Development Goals into the Child Care Subsidy System." Early Childhood Research Quarterly 17 (4): 418-40.

Adams, Gina, Kathleen Snyder, and Jodi R. Sandfort. 2002. "Getting and Retaining Child Care Assistance: How Policy and Practice Influence Parents' Experiences.” Assessing the New Federalism Occasional Paper no. 55. Urban Institute, Washington, DC.

Anderson, Patricia M., and Phillip B. Levine. 2000. "Child Care and Mother's Employment Decisions." 420-62 in Finding Jobs: Work and Welfare Reform, edited by David Card and Rebecca Blank. New York: Russell Sage.

$\rightarrow$ Bainbridge, Jay, Marcia K. Meyers, Sakiko Tanaka, and Jane Waldfogel. 2005. "Who Gets an Early Education? Family Income and the Enrollment of Three- to Five-Year-Olds from 1968 to 2000." Social Science Quarterly 86 (3): 724-45.

Barnett, W. Steven, Jason T. Hustedt, Kenneth B. Robin, and Karen L. Schulman. 2005. The State of Preschool: 2005 State Preschool Yearbook. New Brunswick, NJ: National Institute for Early Education Research.

Besharov, Douglas J., and Caeli A. Higney. 2006. "Federal and State Child Care Expenditures (1997-2003): Rapid Growth Followed by Steady Spending." Report to the U.S. Department of Health and Human Services. University of Maryland, School of Public Policy, Welfare Reform Academy, College Park.

Blank, Helen, Karen L. Schulman, and Danielle T. Ewen. 1999. Key Facts: Essential Information about Child Care, Early Education, and School-Age Care. Washington, DC: Children's Defense Fund.

Blau, David M. 2001. The Child Care Problem: An Economic Analysis. New York: Russell Sage.

$\rightarrow$ Blau, David M., and Alison P. Hagy. 1998. "The Demand for Quality in Child Care." Journal of Political Economy 106 (1): 104-46. 
Butler, Alice, and Melinda Gish. 2003. Head Start Background and Funding. Report to Congress. Washington, DC: Library of Congress, Congressional Research Service.

Campbell, David, and Michael Parisi. 2002. "Individual Tax Returns, 2000." Statistics of Income Bulletin 22 (3): 7-44. http://www.irs.gov/pub/irs-soi/00indtr.pdf.

Caneiro, Pedro, and James J. Heckman. 2003. "Human Capital Policy." 77-239 in Inequality in America: What Role for Human Capital Policies? edited by James J. Heckman, Alan B. Krueger, and Benjamin N. Friedman. Cambridge MA: MIT Press.

Council of State Governments. 1993. The Book of the States, vol. 27. Lexington, KY: Council of State Governments.

- 1994. The Book of the States, vol. 28. Lexington, KY: Council of State Governments. 1995. The Book of the States, vol. 29. Lexington, KY: Council of State Governments. 1996. The Book of the States, vol. 30. Lexington, KY: Council of State Governments. 1997. The Book of the States, vol 31. Lexington, KY: Council of State Governments.

$\rightarrow$ Crosby, Danielle A., Lisa A. Gennetian, and Aletha C. Huston. 2005. "Child Care Assistance Policies Can Affect the Use of Center-Based Care for Children in Low-Income Families." Applied Developmental Science 9 (2): 86-106.

Crouse, Gil. 1999. "State Implementation of Major Changes to Welfare Policies, 1992-1998." U.S. Department of Health and Human Services, Assistant Secretary for Planning and Evaluation, Office of Human Services Policy, Washington, DC. http://aspe.hhs.gov/ hsp/waiver-policies99/policy_CEA.htm.

Culkin, Mary L., Scott Groginsky, and Stephen M. Christian. 1997. Building Blocks: A Legislator's Guide to Child Care Policy. Denver: National Conference of State Legislatures.

$\rightarrow$ Currie, Janet. 2001. "Early Childhood Education Programs." Journal of Economic Perspectives 15 (2): 213-38.

Donahue, Elisabeth Hirschhorn, and Nancy Duff Campbell. 2002. "Making Care Less Taxing: Improving State Child and Dependent Care Tax Provisions." Report, 2002 rev. National Women's Law Center, Washington, DC. http://www.nwlc.org/pdf/ MakingCareLessTaxing2002.pdf.

Federal Interagency Forum on Child and Family Statistics. 2003. America's Children: Key National Indicators of Well-Being, 2003. Washington, DC: U.S. Government Printing Office. http://www.childstats.gov/pubs.asp.

$\rightarrow$ Fuller, Bruce, Sharon L. Kagan, Gretchen L. Caspary, and Christiane A. Gauthier. 2002. "Welfare Reform and Child Care Options for Low-Income Families." Future of Children 12 (1): 97-119.

$\rightarrow$ Gennetian, Lisa A., Danielle A. Crosby, Aletha C. Huston, and Edward D. Lowe. 2004. "Can Child Care Assistance in Welfare and Employment Programs Support the Employment of Low-Income Families?” Journal of Policy Analysis and Management 23 (4): $723-43$.

Gish, Melinda. 2002. Child Care: Funding and Spending under Federal Block Grants. Report to Congress. Washington, DC: Library of Congress, Congressional Research Service.

$\rightarrow$ Hofferth, Sandra L., and Douglas A. Wissoker. 1992. "Price, Quality, and Income in Child Care Choice." Journal of Human Resources 27 (1): 70-111.

$\rightarrow$ Huston, Aletha C., Young Eun Chang, and Lisa A. Gennetian. 2002. "Family and Individual Predictors of Child Care Use by Low-Income Families in Different Policy Contexts." Early Childhood Research Quarterly 17 (4): 441-69.

Johnson, Nicholas, Christina Smith Fitzpatrick, and Elizabeth C. McNichol. 1999. "State Income Tax Burdens on Low-Income Families in 1998: Assessing the Burden and Opportunities for Relief.” Report. Center on Budget and Policy Priorities, Washington, DC.

Johnson, Nicholas, Michael Mazerov, Elizabeth McNichol, and Alan Berube. 1998. "State Income Tax Burdens on Low-Income Families in 1997: Assessing the Burden and Opportunities for Relief." Report. Center on Budget and Policy Priorities, Washington, DC.

Johnson, Nicholas, Robert Zahradnik, and Elizabeth C. McNichol. 2000. "State Income Tax Burdens on Low-Income Families in 1999." Report. Center on Budget and Policy Priorities, Washington, DC.

Karoly, Lynn A., Peter W. Greenwood, Susan S. Everingham, Jill Hoube, M. Rebecca Kilburn, C. Peter Rydell, Matthew Sanders, and James Chiesa. 1998. Investing in Our Children: What We Do and Don't Know about the Costs and Benefits of Early Childhood Interventions. Santa Monica, CA: RAND. 


\section{Social Service Review}

Lee, Valerie E., and David T. Burkam. 2002. Inequality at the Starting Gate: Social Background Differences in Achievement as Children Begin School. Washington, DC: Economic Policy Institute.

$\rightarrow$ Lowe, Edward D., and Thomas S. Weisner. 2004. "You Have to Push It-Who's Gonna Raise Your Kids?': Situating Child Care and Child Care Subsidy Use in the Daily Routines of Lower Income Families." Children and Youth Services Review 26 (2): 143-71.

$\rightarrow$ Magnuson, Katherine A., Marcia K. Meyers, Christopher J. Ruhm, and Jane Waldfogel. 2004. "Inequality in Preschool Education and School Readiness." American Educational Research Journal 41 (1): 115-57.

Manzi, Nina, and Joel Michael. 2006. Minnesota Individual Alternative Minimum Tax. Short Subjects report. St. Paul: Minnesota House of Representatives, Research Department. http://www.house.leg.state.mn.us/hrd/issinfo/ssmnamt.pdf.

McNichol, Elizabeth C., and Edward B. Lazere. 1997. "Most States Still Tax the Working Poor after Five Years of Economic Recovery." Report. Center on Budget and Policy Priorities, Washington, DC. http://www.cbpp.org/sttax.htm.

$\rightarrow$ Meyers, Marcia K., Theresa C. Heintze, and Douglas A. Wolf. 2002. "Child Care Subsidies and the Employment of Welfare Recipients." Demography 39 (1): 165-79.

$\rightarrow$ Meyers, Marcia K., and Lucy P. Jordan. 2006. "Choice and Accommodation in Parental Child Care Decisions.” Community Development 37 (2): 53-70.

Meyers, Marcia K., Dan T. Rosenbaum, Christopher J. Ruhm, and Jane Waldfogel. 2004. "Inequality in Early Childhood Education and Care: What Do We Know?" 223-70 in Social Inequality, edited by Kathryn N. Neckerman. New York: Russell Sage.

$\rightarrow$ Michalopoulos, Charles, and Philip K. Robins. 2000. "Employment and Child-Care Choices in Canada and the United States." Canadian Journal of Economics 33 (2): 435-70.

$\rightarrow-$ 2002. "Employment and Child Care Choices of Single-Parent Families in Canada and the United States." Journal of Population Economics 15 (3): 465-93.

Moffitt, Robert. n.d. Welfare Benefits Database. Johns Hopkins University, Department of Economics, Baltimore. http://www.econ.jhu.edu/People/Moffitt/DataSets.html (accessed March 11, 2003).

National Conference of State Legislatures. 1998. "1998 Partisan Composition of State Legislatures." National Conference of State Legislatures, Denver. http://www.ncsl .org/ncsldb/elect98/partcomp.cfm?yearsel $=1998$.

—_ 1999. "State Vote 1999." National Conference of State Legislatures, Denver. http://www.ncsl.org/programs/legismgt/elect/1999Election.htm.

— 2000. "State Vote 2000." National Conference of State Legislatures, Denver. http://www.ncsl.org/programs/legismgt/statevote/statevote2000.htm.

$\rightarrow$ Powell, Lisa M. 1997. "The Impact of Child Care Costs on the Labour Supply of Married Mothers: Evidence from Canada." Canadian Journal of Economics 30 (3): 577-94.

$\rightarrow-$. 2002. "Joint Labor Supply and Childcare Choice Decisions of Married Mothers." Journal of Human Resources 37 (1): 106-28.

$\rightarrow$ Pungello, Elizabeth, and Beth Kurtz-Costes. 1999. "Why and How Working Women Choose Child Care: A Review with a Focus on Infancy.” Developmental Review 19 (1): 31-96.

Rosenbaum, Dan T., and Christopher J. Ruhm. 2005. "The Cost of Caring for Young Children.” Working Paper no. 11837. National Bureau of Economic Research, Cambridge, MA.

Schulman, Karen L., Helen Blank, and Danielle T. Ewen. 1999. Seeds of Success: State Prekindergarten Initiatives, 1998-1999. Washington, DC: Children's Defense Fund.

Shonkoff, Jack P., and Deborah Phillips, eds. 2000. From Neurons to Neighborhoods: The Science of Early Childhood Development. Washington, DC: National Academy Press.

$\rightarrow$ Singer, Judith D., Bruce Fuller, Margaret K. Keiley, and Anne Wolf. 1998. "Early ChildCare Selection: Variation by Geographic Location, Maternal Characteristics, and Family Structure." Developmental Psychology 34 (5): 1129-44.

Smolensky, Eugene, and Jennifer A. Gootman, eds. 2003. Working Families and Growing Kids: Caring for Children and Adolescents. Washington, DC: National Academies Press.

Steinschneider, Janice, Nancy Duff Campbell, and Verna L. Williams. 1994. "Making Care Less Taxing: Improving State Child and Dependent Care Tax Provisions." Report. National Women's Law Center, Washington, DC.

Steinschneider, Janice, Elisabeth Hirschhorn Donahue, Nancy Duff Campbell, and Verna 
L. Williams. 1998. "Making Care Less Taxing: Improving State Child and Dependent Care Tax Provisions." Report, 1998 rev. National Women's Law Center, Washington, DC. http://www.nwlc.org/pdf/Making_Care_Less_Taxing.pdf.

Tekin, Erdal. 2004. "Child Care Subsidy Receipt, Employment, and Child Care Choices of Single Mothers." Working Paper no. 10459. National Bureau of Economic Research, Cambridge, MA.

Urban Institute. n.d. Welfare Rules Database. Urban Institute, Assessing the New Federalism Research Policy Center, Washington, DC. http://anfdata.urban.org/drsurvey/ login.cfm?CFID = 164120\&CFTOKEN $=63462333($ accessed on March 11, 2003).

U.S. Census Bureau. 1993. Statistical Abstract of the United States, 1992. 112th ed. Washington, DC: U.S. Census Bureau.

- 1994. Statistical Abstract of the United States, 1993. 113th ed. Washington, DC: U.S. Census Bureau.

1995. Statistical Abstract of the United States, 1994. 114th ed. Washington, DC: U.S. Census Bureau.

1996. Statistical Abstract of the United States, 1995. 115th ed. Washington, DC: U.S. Census Bureau.

1997. Statistical Abstract of the United States, 1996. 116th ed. Washington, DC: U.S. Census Bureau.

. 1998. Statistical Abstract of the United States, 1997. 117th ed. Washington, DC: U.S. Census Bureau.

1999. Statistical Abstract of the United States, 1998. 118th ed. Washington, DC: U.S. Census Bureau.

. 2000a. "Poverty Thresholds in 2000, by Size of Family and Number of Related Children under 18 Years." U.S. Census Bureau, Washington, DC. http://www .census.gov/hhes/poverty/threshld/thresh00.html.

. 2000b. Statistical Abstract of the United States, 1999. 119th ed. Washington, DC: U.S. Census Bureau.

2001. Statistical Abstract of the United States, 2000. 120th ed. Washington, DC: U.S. Census Bureau.

2003. Statistical Abstract of the United States, 2002. 122nd ed. Washington, DC: U.S. Census Bureau.

. 2006. Statistical Abstract of the United States, 2006: The National Data Book. 125th ed. Washington, DC: U.S. Census Bureau.

West, Jerry, Kristin Denton, and Elvie Germino-Hausken. 2000. "America's Kindergartners: Findings from the Early Childhood Longitudinal Study, Kindergarten Class of 1998-1999: Fall 1998." Education Statistics Quarterly 2 (1): 7-13.

USDHHS (U.S. Department of Health and Human Services), Administration for Children and Families. 2001. "2001 Head Start Fact Sheet." USDHHS, Administration for Children and Families, Washington, DC. http://www.acf.hhs.gov/programs/hsb/ research/factsheets/01_hsfs.htm.

USDHHS (U.S. Department of Health and Human Services), Child Care Bureau. 2002. "Child Care Development Fund (CCDF) FFY 2000 Tables and Charts." USDHHS, Child Care Bureau, Washington, DC. http://www.acf.hhs.gov/programs/ccb/research/ 00acf800/cover.htm.

USDHHS (U.S. Department of Health and Human Services), Office of the Assistant Secretary for Planning and Evaluation. 2001. Trends in the Well-Being of America's Children and Youth, 2001. Report. Washington, DC: USDHHS, Office of the Assistant Secretary for Planning and Evaluation. http://aspe.hhs.gov/hsp/01trends/index.htm.

Witte, Ann Dryden, and Marisol Trowbridge. 2004. "The Structure of Early Care and Education in the United States: Historical Evolution and International Comparisons." Working Paper no. 10931. National Bureau of Economic Research, Cambridge, MA.

Zahradnik, Robert, Nicholas Johnson, and Michael Mazerov. 2001. "State Income Tax Burdens on Low-Income Families in 2000: Assessing the Burden and Opportunities for Relief." Report. Center on Budget and Policy Priorities, Washington, DC. 


\section{Social Service Review}

\section{Notes}

1. Formal care is broadly defined throughout this article to include enrollment in public preschools, public prekindergarten programs, and private preschool and nursery schools. It also includes enrollment in child-care centers that surveyed parents designated as school for 3- and 4-year-old children. It excludes care in family child-care homes as well as care provided by friends, relatives, babysitters, or nannies.

2. Federal and state dependent-care (child-care) tax credits also provide support for families purchasing private care, but few low-income families benefit from the credit. The federal dependent-care tax credit amounted to about $\$ 2.8$ billion in 2000 (Campbell and Parisi 2002).

3. Prior to 1996, two other sources of child-care subsidies provided support to lowincome families. Assistance was available to families transitioning from welfare to work (Transitional Child Care) and families at risk of receiving welfare (At Risk Child Care). These programs were replaced by the CCDF and TANF block grants in 1996 .

4. Information is not collected on the quality of care that children experience or the number of hours in which they attend formal care.

5. The NHES and NSAF data cannot be used for the analyses in this study because they are available only for selected years.

6. Data on maternal education are missing from the records for 1,174 children. Missing data dummy variables are used so that cases with missing data can be included in the sample. The missing data dummy predicts a $0.012(p<.05)$ increase in the probability of being in formal care among the low-income sample. It predicts a $0.030(p<.05)$ increase in the probability of being in formal care in the higher-income sample. The comparison group is mothers with less than a high school degree.

7. Under welfare reform, the TANF and CCDF programs require states to match federal funding for those programs with states' own MOE expenditures, but states can count the same MOE expenditures toward the requirements of each program and are not required to report how much their MOE spending from one program overlaps with that for the other. Because of concerns that states may therefore overstate their expenditures, the Congressional Research Service only counts the portion of a state's MOE TANF spending that exceeds their MOE CCDF spending.

8 . Adjustment is made for the number of poor children under age 13, because children up to that age are eligible for child-care subsidies. For ease of interpretation, the same scaling is used for Head Start. However, the pattern of findings is not sensitive to the choice of denominator. About 60 percent of CCDF funds are provided to children under age 6 (USDHSS, Child Care Bureau 2002).

9. Nebraska is the only state with a unicameral legislature. The missing data for Nebraska's percentage of Republicans in the state senate is replaced with a value of zero. A missing data dummy variable is not used because it is collinear with a state indicator and analyses include state fixed effects.

10. Although tax credits constitute a large share of total public spending on early care and education, the present analysis does not include federal child-care tax credits, because there were no changes to this portion of the tax code during the 1990s. The analysis does not include indicators of state nonrefundable credits, because low-income families are unlikely to receive these credits and they are typically small. Another possible funding source that expanded during the 1990s was the federal EITC. Although the EITC is not technically a child-care program, parents could use money from the EITC payments to cover the costs of child care. Because expansions to the federal EITC would affect all states equally, they are not included in the model.

11. For example, in 5 out of the 9 years under study, Vermont had five or fewer children in poverty. It is thus not surprising that the state's data show large year-to-year fluctuations in enrollment rates (of up to 25 percentage points).

12. Because of the selective nature of the data, results are presented from analyses conducted without sampling weights. However, findings do not differ with the inclusion of weights.

13. In the 1996 child-care subsidy funding, the decrease is due to inflation and sample composition. Total combined unadjusted spending increased very slightly from 1995 to 1996. 
14. The year-to-year enrollment rates for low- and higher-income children in this sample differ slightly from the rates for the full sample from all 50 states (table A3), but the gain is nearly identical for the low-income sample and 3 percentage points larger for the higherincome sample. Changes in average enrollment from 1999 to 2000 favor low-income children, but even if one considers the time period from 1992 to 1999, low-income children have a slightly larger increase in enrollment than that for higher-income children.

15. Results from regression analyses with child and family controls, but without state and year fixed effects, suggest slightly larger estimated effects of public funding on lowincome children's enrollment. The spending coefficient in a model without any fixed effects or with only state fixed effects is approximately 0.017 ; for a model with only year fixed effects, the coefficient is 0.014 .

16. Analyses that control for a larger set of welfare policy measures (severity of sanctions, shortness of time limit, immediate work requirements, and family cap policies) yield coefficients of a similar magnitude $(0.014, p<.10)$.

17. In models that do not contain either the state per capita income or or the expenditure measure, the coefficients for the set of year dummy variables estimates range from -0.02 to 0.02 and are not statistically significant.

18. Introducing interaction terms for low income and state effects further increases the magnitude of the interaction term (low income by spending) to $0.008(p<.05)$.

19. In analyses with the bottom 20 percent of the income distribution, the sample is limited to children residing in states and to children in years in which at least 15 children are in families with incomes in the bottom 20 percent of the distribution.

20. Between 1994 and 2000, the estimated increase in public funding, including prekindergarten, amounted to about $\$ 780$ per poor child under age 13 . This suggests that about 9 percentage points of the increase from 1994 to 2000 is due to increased public support for early education programs.

21. Given the noise in the data, the prekindergarten effects are imprecisely estimated. In the interaction analyses, the main effect of prekindergarten is -0.034 (not statistically significant), and the interaction term (4-year-old by prekindergarten spending) is 0.053 $(p<.01)$. 